\title{
Health effects of exposure to chlorination by-products in swimming pools: Position Paper
}

\author{
Mariana Couto ${ }^{1}$, Alfred Bernard ${ }^{2}$, Luís Delgado ${ }^{3}$, Franchek Drobnic ${ }^{4}$, Marcin Kurowski $^{5}$, \\ André Moreira ${ }^{3}$, Rodrigo Rodrigues-Alves ${ }^{6}$, Maia Rukhadze $^{7}$, Sven Seys ${ }^{8}$, Marta \\ Wiszniewska $^{9}$, and Santiago Quirce ${ }^{10}$ \\ ${ }^{1}$ Hospital CUF Descobertas \\ ${ }^{2}$ Louvain Center for Toxicology and Applied Pharmacology (LTAP) \\ ${ }^{3}$ University of Porto Faculty of Medicine \\ ${ }^{4}$ Olympic Training Center \\ ${ }^{5}$ Medical University of Lodz \\ ${ }^{6}$ Hospital do Divino Espírito Santo de Ponta Delgada EPE \\ ${ }^{7}$ Center of Allergy and Immunology \\ ${ }^{8} \mathrm{KU}$ Leuven \\ ${ }^{9}$ Nofer Institute of Occupational Medicine \\ ${ }^{10}$ Hospital LA Paz Health Research Institute (IdiPaz)
}

February 23, 2021

\begin{abstract}
Concerns have been raised regarding the potential negative effects on human health of water disinfectants used in swimmingpools. Among the disinfection options, the approaches using chlorine-based products have been typically preferred. Chlorine readily reacts with natural organic matter that are introduced in the water mainly through the bathers, leading to the formation of potentially harmful chlorination by-products (CBPs). The formation of CBPs is of particular concern since they have been epidemiologically associated with the development of various clinical manifestations. The higher the concentration of these volatile CBPs in the water, the higher their concentration in the air above the pool, and different routes of exposure to chemicals in swimming-pools (water ingestion, skin absorption and inhalation) contribute to the individual exposome. CBPs may affect the respiratory and skin health of those who stay indoor for long periods, such as swimming instructors, pool staff, and competitive swimmers. Whether those who use chlorinated-pools as customers, particularly children, may also be affected has been a matter of debate. In this article, the EAACI Joint Task Force of the Working Group of Allergy, Asthma \& Sports and the Interest Groupf of Environmental \& Occupational Allergy discusses the current evidence regarding the health effects of both acute and chronic exposures in different populations (work-related exposures, intensive sports and recreational attendance) and identify the main recommendations and unmet needs for research in this area.
\end{abstract}

\section{INTRODUCTION}

The quality of the water and the air of swimming-pools is currently a topic of interest in occupational and environmental health. Even though the beneficial effects of swimming on increasing physical activity, cardiopulmonary fitness and improving lung function are undeniable ${ }^{1}$, concerns have been raised regarding the potential negative effects on human health of water disinfectants used in swimming-pools.

The World Health Organization (WHO) highlights the need of adequate water disinfection of swimmingpools to prevent microbial proliferation. Disinfectants are the principal management-derived chemicals 
added to minimize the risk of microbial contaminants, and although several options are available (bromine, ozone, copper-silver, UV irradiation, electrochemically generated mixed oxidants, UV/hydrogen peroxide, etc) chlorine-based products have been typically preferred due to their effectiveness and lower overall relative cost, in spite of possibly leading to unwanted effects.

Indoor swimming-pools are of particular concern since they are used regularly all year round, and volatile chlorination by-products (CBPs) can become trapped within the swimming-pool complexes indoor air. The higher the concentration of these volatile CBPs in the water, the higher their concentration in the air above the $\mathrm{pool}^{2}$. Besides inhalation of volatile or aerosolized solutes, there are two other main routes of exposure to chemicals in swimming-pools: water ingestion, and skin absorption (which may represent a source of muco-cutaneous symptoms). These several routes add to the individual "exposome", which comprises all environmental exposures that a person experiences from conception throughout the lifespan ${ }^{3}$.

CBPs may affect the respiratory and skin health of those who stay indoor for long periods, such as swimming instructors, pool staff, and competitive swimmers. Whether those who use chlorinated-pools as customers, particularly children, may also be affected has been a matter of debate. We aimed to review this topic, by describing the chemical and toxicity of these compounds given the types of exposure and reviewing health effects of such exposures in different populations considering also personal and environmental risk factors, in order to propose recommendations and to identify unmet needs in this area.

\section{THE SWIMMING POOL ENVIRONMENT}

Swimming-pool environment is a complex and dynamic ecosystem that can be affected by the type of swimming-pool (indoor, outdoor,...) and by other factors, including water temperature, ventilation, climate, location, purpose of use (competition, relaxation, recreational activities) and swimming habits, particularly swimmer's hygiene ${ }^{4-6}$. In the case of an indoor swimming-pool, the environment consists of the water in the pool, the air above the pool within the natatorium, and the people in the pool (biota) ${ }^{2}$.

Both organic and inorganic compounds are continuously entering this ecosystem via filling waters (tap water, seawater, thermal water...), disinfectant addition (chlorine, bromine, ozone, UV...), pharmaceuticals and personal care products (analgesics, antibiotics, sunscreens, lotions, cosmetics, soaps...) and human body excretions (urine, sweat, saliva...). Interactions between all these compounds generates CBPs, some of which are of health concern ${ }^{7}$.

The addition of chlorine-based disinfectants (chlorine gas, sodium or calcium hypochlorite, di- or trichloroisocyanurates) to the swimming-pools water releases hypochlorous acid $(\mathrm{HClO})$, which is the active biocide. $\mathrm{HClO}$ is a weak acid with a pKa of 7.5 at $25^{\circ} \mathrm{C}$ that reversely dissociates into hypochlorite $\left(\mathrm{ClO}^{-}\right)$and hydrogen ion. The sum of $\mathrm{HClO}$ and $\mathrm{ClO}^{-}$is referred to as free chlorine. $\mathrm{HClO}$ is a non-specific biocide that inactivates most waterborne pathogens but also reacts with organic matter to produce a wide range of $\mathrm{CBPs}^{8}$. Compared to tap water, CBPs formation in pools is much more important due to the higher input of organic matter and the constant addition of disinfectants ${ }^{9}$. In chlorinated-pools, major groups of CBPs include chloramines, trihalomethanes (THMs), haloacetics acids (HAAs), haloacetaldehydes (HALs) and haloacetonitriles (HANs) (Figure 1 ).

Chloramines are formed as a result of the reaction of $\mathrm{HClO}$ with urea and other nitrogenous compounds brought by swimmers. This group comprises monochloramine (chloramide, $\mathrm{NH}_{2} \mathrm{Cl}$ ), dichloramine (chlorimide, $\mathrm{NHCl}_{2}$ ) and trichloramine (nitrogen trichloride, $\mathrm{NCl}_{3}$ ). Monochloramine and dichloramine (the sum of which is referred to as combined chlorine) are mainly found in water. Trichloramine, which is 400 times more volatile than its two congeners, is mainly found in the air at levels that are inversely proportional to the ventilation rate of indoor swimming-pools ${ }^{10,11}$. The odour and taste of water are mainly affected by the monochloramine/dichloramine ratio and the trichloramine concentration. This last compound is also responsible for the distinctive odour of indoor pools, wrongly attributed to chlorine ${ }^{9}$.

THMs represent between 5 to $10 \%$ of total organohalogens in swimming-pool water and air, with chloroform $\left(\mathrm{CHCl}_{3}\right)$ being the dominant species ${ }^{8}$. THMs are generated from the complex reaction between active chlorine 
and naturally present or imported carbonaceous organic matter. Parameters influencing the formation of THMs include: organic matter concentration, chlorine concentration, contact time, water $\mathrm{pH}$, temperature, and bromine ion concentrations ${ }^{12}$. THMs are generally well absorbed by inhalation, ingestion or skin contact.

Haloacetics acids (HAAs), haloacetaldehydes (HALs) and haloacetonitriles (HANs) are less frequent CBPs and therefore described in theonline supplementary material .

\section{EFFECTS OF ACUTE EXPOSURES}

Pool chemical-associated health events result in $>4.500$ emergency department visits annually during 20082017 in US, as reported by the CDC, and over one-third were children or teenagers. Irritated eye, nose and throat symptoms, and asthma, are the most frequent symptoms in swimmers and workers of indoor swimming-pools caused by CBPs; particularly $\mathrm{NCl}_{3}$ causes the most irritative symptoms ${ }^{13,14}$. A significant concentration-response relation was found between $\mathrm{NCl}_{3}$ exposure concentrations and irritant eye, nasal, and throat symptoms ${ }^{15}$.

\section{Respiratory symptoms}

Cold and sneezing are the most frequent self-reported complaints (65.4\% and $52.6 \%$, respectively) while only $7.5 \%$ of the total indoor swimming-pools workers reported an asthmatic condition ${ }^{13}$. It is discussed whether recreational swimming or working in indoor swimming-pools may aggravate asthma or actually cause $i t^{16}$. Irritant-induced asthma (IIA) is defined as development of asthma, nonspecific bronchial hyperresponsiveness (BHR), and airway inflammation induced by irritant mechanisms, as opposed to occupational asthma (OA) caused by immunologic mechanisms ${ }^{17}$. Three cases of $\mathrm{OA}$ in swimming-pool workers have been documented $^{18}$, two of them had a positive bronchial provocation test to chloramine. Another study with a large sample of swimming-pool workers $(\mathrm{n}=624)$ also showed increased risk of respiratory symptoms indicative of asthma upon $\mathrm{NCl}_{3}$ exposure ${ }^{14}$.

\section{Short-term changes in respiratory biomarkers}

CBPs have a strong oxidizing potential and may contribute to airway damage through opening tight junctions, causing barrier disruption ${ }^{19,20}$. A summary of the studies describing short-term changes in respiratory biomarkers is presented inTable 1 . It is important to note that some of these studies did not measure $\mathrm{NCl}_{3}$ and/or did not compare with a non-chlorinated-pool, which precludes drawing clear conclusions. The role of physical activity should not be neglected in this type of studies measuring biomarkers before and after swimming.

Non-respiratory symptoms

Concerning self-reported ocular symptoms, indoor swimming-pools employees declared frequently having red $(48.9 \%)$ and itchy $(44.4 \%)$ eyes, mostly lifeguards and trainers ${ }^{13}$.

Regarding the skin, both water itself and CBPs have negative effects due to a dilution or flushing out of the natural moisturizing. An increasing risk of irritative skin symptoms was demonstrated dependent on the $\mathrm{NCl}_{3}$ concentrations ${ }^{21}$. Recreational swimming leads to transient but significant changes in skin surface properties of women with healthy $\operatorname{skin}^{22}$; skin dryness, itch and erythema are non-specific complains in swimming-pool attendants ${ }^{23,24}$. Additionally, both allergic contact dermatitis and contact urticaria due to chlorinated-pool water have been identified ${ }^{20,23,25,26}$. Swimming in public pools/spas in the current or previous week has been associated with dermal symptoms (rash, generalized itching, dermal infection) ${ }^{27}$. Besides, more verrucas, mycosis, eczema and rash have been identified in lifeguards and trainers compared to other workers at swimming pools ${ }^{13}$.

Three different disinfection systems (chlorine, chlorine/ozone and bromine/ozone) were investigated to assess adverse skin and eye effects ${ }^{28}$ : compared with the bromine/ozone pool, the odds ratio (OR) of having a rash $<24 \mathrm{~h}$ after pool use was 1.91 (CI 0.71-5.10) for the chlorine-pool and 1.88 (CI 0.61-5.81) for the chlorine/ozone pool. Goma et al. ${ }^{29}$ reported the efficacy of a new disinfection method (based upon on replacement of the strong $\mathrm{HCl}$ by $\mathrm{CO}_{2}$, inclusion of a low concentration salt electrolysis system, and ultraviolet 
radiation phase) to markedly reduce the irritant substances levels in the pool atmosphere and significantly reduce eye, nose, skin and cough complaints, both in recreational and competitive swimmers.

\section{EFFECTS OF CHRONIC EXPOSURES}

Studies based on serum pneumoproteins show that not only acute but also chronic exposure to $\mathrm{NCl}_{3}$ can increase the lung epithelium permeability and thereby perhaps facilitate the transepithelial delivery of allergens to dendritic cells ${ }^{30}$ and contribute to a T2-dependent immune response ${ }^{31,32}$. Recent experimental evidence in mice has shown that chronic chlorine inhalation contributes to exacerbate airways inflammation in asthma by mobilizing pro-inflammatory macrophages into the lung as well as stimulating group 2 and 3 $\mathrm{ILCs}^{33}$.

The barrier disruption effect may occur also on the dermal layer. The high temperature of the water, the hydration of the skin and the disrupting effects of CBPs on the skin barrier are all factors that in combination decrease the water-holding capacity of the skin stratum corneum ${ }^{34}$ and greatly facilitate the permeation of CBPs across the skin, especially thin areas such as the scrotum.

\section{Work-related exposure}

Lifeguards, swim teachers and physiotherapists have the highest CBPs cumulative exposure when compared to other swimming-pool workers ${ }^{21}$. In order to protect workers but also swimmers, WHO has imposed a reference value for $\mathrm{NCl}_{3}$ of $0.5 \mathrm{mg} / \mathrm{m}^{3}$. However, airborne $\mathrm{NCl}_{3}$ is not regularly monitored in most European countries.

Dose-response relationships between $\mathrm{NCl}_{3}$ levels and different respiratory (runny nose, blocked nose, voice loss) and ocular (red or itchy eyes) symptoms have been reported from a level of $0.5 \mathrm{mg} / \mathrm{m}^{3}$ onwards ${ }^{35}$. Interestingly, another study demonstrated increasing risk of respiratory symptoms up to a level of 0.2-0.3 $\mathrm{mg} / \mathrm{m} 3$ of $\mathrm{NCl}_{3}$, urging to revisit the WHO occupational exposure limit ${ }^{21}$. This is also in line with other study, where very low levels of $\mathrm{NCl}_{3}$ in indoor swimming-pools $(0.017-0.15 \mathrm{mg} / \mathrm{m} 3)$ were detected with increased risk for sore throat (OR: 11.28; 95\% CI: 1.44-88.33) and phlegm (OR: 4.22; 95\% CI: 1.16-15.4) ${ }^{36}$.

Upper and lower respiratory symptoms while on duty were related to duration of lifetime exposure. Lifeguards exposed $>500$ hours in the previous 12 months experienced more cough, throat and eye irritation than nonor less-exposed lifeguards, and those with prior asthma had a significantly higher risk of suffering from asthma attack(s) than non-exposed asthmatic subjects ${ }^{37}$. Physician-diagnosed asthma was high among lifeguards $(23 \%)^{37}$.

\section{Intensive sports}

\section{Respiratory symptoms}

Competitive and synchronized swimming ranked second among sport disciplines associated with increased prevalence of asthma symptoms ${ }^{38}$. The long-term exposure to CBPs in a sport setting underlines some aspects: 1) the role in inducing and sustaining airway inflammation; 2) the contribution to airway remodeling; and 3) possible promotion of allergic sensitization in regularly exposed competitive swimmers.

A significantly higher rate of BHR with increased inflammatory parameters have been observed in elite swimmers. Long-term swimming-pool exposure effects included increase in both eosinophilic and neutrophilic inflammation, as reflected not only in sputum cell counts but also in higher concentration of sputum eosinophil peroxidase and human neutrophil lipocalin, respectively ${ }^{39}$. Inflammatory and remodeling changes reported in bronchial biopsies of competitive swimmers were similar to non-exercising mild asthmatics and were present also during off-training period. Discontinuation of a swimming career decreases eosinophilic and neutrophilic inflammation and reduces BHR, although these findings should be interpreted with caution given the small sample sizes ${ }^{40,41}$. These inflammatory changes did not seem, however, to correlate with BHR. A study carried out in a mixed population of competitive athletes including mostly non-asthmatic swimmers and speed skaters indicated that the baseline pattern of proinflammatory cytokine TNF- $\alpha$ and anti-inflammatory 
IL-1ra concentrations in the lower airways appear to be similar in top level athletes and asthmatic patients, but different in healthy controls ${ }^{42}$.

Increased airway edema due to CBPs-induced vascular leakage has been also hypothesized for airway inflammation in swimmers. A significant association of vascular permeability index (quotient of albumin levels in sputum and in serum) with increased sputum eosinophil and neutrophil counts was found ${ }^{43}$, although vascular leakage did not correlate with lung function and BHR. In synchronized swimmers no evidence was found for negative influence of CBPs on the pulmonary function ${ }^{44}$.

A study assessing rhinitis in swimmers showed $44 \%$ presented baseline allergic rhinitis and $35 \%$ had inflammation with neutrophilic predominance ${ }^{45}$. Neutrophilic influx is mainly attributed to irritation through CBPs exposure and is possibly reversed - contrarily to eosinophil infiltration - after nose clip introduction ${ }^{45}$. Mucociliary transport impairment and reduced ciliary beats frequency have been described in swimmers and also attributed to irritation by CBPs. Nasal lavage fluid (NLF) collected immediately after competitive swimming contains more neutrophils with decreased phagocytic activity. However, NLF changes tend to subside in swimmers shortly after training cessation or introduction of protective measures, such as nose clip $^{46}$. In the study ${ }^{42}$ involving swimmers and speed skaters, TNF- $\alpha$ concentrations in nasal secretions were similar between athletes, asthmatics and healthy controls. However, IL-1ra levels in upper airways were higher in athletes and asthmatics than healthy subjects. Seemingly paradoxical, this fact may reflect a local anti-inflammatory response of the nasal mucosa.

Non-respiratory symptoms

A wide spectrum of dermatoses of various etiologies (infectious, traumatic, irritant, allergic, neoplastic etc.) are listed in the context of regular swimming-pools use or aquatic sports performance ${ }^{47}$. Xerosis is one of the most frequent condition experienced by swimmers ${ }^{48}$, and especially among those with sensitive and eczematous skin ${ }^{49}$. The dryness effect is particularly pronounced in atopic skin, since the threshold residual chlorine concentration required for considerable drop in water-holding properties is significantly lower than in healthy subjects $(0.5 \mathrm{mg} / \mathrm{l} \text { vs. } 2.0 \mathrm{mg} / \mathrm{l} \text {, respectively })^{34}$, possibly explaining why the higher probability of skin symptoms compared to other disinfection methods (bromine, ozone, UV lamps and salt electrolysis) ${ }^{49}$. Also eye symptoms are more significantly associated with chlorine-disinfected pools, comparing with other disinfection methods ${ }^{49}$ and often listed as a common problem in competitive swimmers. The risk of otitis externa in swimmers and polo players was higher than in soccer players ${ }^{50}$.

\section{Recreational attendance}

Table 2 summarizes studies that have investigated the respiratory effects of $\mathrm{NCl}_{3}$ and other inhalable CBPs among recreational swimmers. The first study was conducted among schoolchildren in Belgium ${ }^{51}$. While assessing the effects of ambient air pollution, the authors unexpectedly found that indoor chlorinated-pools attendance correlated with lung epithelium hyperpermeability and asthma prevalence. Further studies in Belgium revealed that the asthma risk among adolescents and children using chlorinated-pools stems from an interaction with atopic status ${ }^{52,53}$. Of interest, also the risk of allergic asthma was most strongly linked to pool attendance during early childhood ${ }^{52}$. Two studies in Sweden confirmed these observations while showing that the risk of allergic asthma correlated with the cumulative inhalation exposure to $\mathrm{NCl}_{3}{ }^{54,55}$.

Associations between asthma and recreational swimming in chlorinated-pools were also reported in Ireland ${ }^{56}$, Italy $^{57}$ and Portugal ${ }^{58}$. Several other studies, however, provided no evidence of an increased asthma risk in recreational swimmers ${ }^{59-62}$. Of these, one of the most contradictory but also the most influential owing to its large size is the UK prospective birth cohort study (ALSPAC study) ${ }^{61}$, which was suggestive, if anything, of a protective effect of swimming towards asthma risk. There are several possible explanations for these contrasting observations. A first explanation is that children examined in these negative studies ${ }^{59-62}$ were too young to detect associations with allergic asthma. Another possible explanation is an underestimation of the exposure with consequently a risk of miss-classifying some categories of swimmers ${ }^{63,64}$.

Associations have also been reported between indoor chlorinated-pool attendance and the risks of allergic 
rhinitis $^{53,65}$, autonomic changes ${ }^{58}$ and airway inflammation assessed by the exhaled NO test ${ }^{52}$. Further complicating the issue, some studies suggest that early swimming in chlorinated-pools may increase the risks of allergic sensitization in particular to perennial allergens ${ }^{62,66,67}$.

Last, respiratory risks when swimming in chlorinated-pools are probably not limited to the exposure to $\mathrm{NCl}_{3}$. Swimming in indoor chlorinated-pools during infancy has also been associated with a higher risk of bronchiolitis or recurrent respiratory infection mainly in children with family history of atopic diseases ${ }^{9,68,69}$.

Biomarkers studies have revealed that the attendance of chlorinated-pools correlates with a disruption of airway epithelial barrier as reflected by altered serum levels of lung epithelium-specific proteins (pneumoproteins). Several studies have shown that early swimming in chlorinated-pools is associated with decreased serum levels of CC16 ${ }^{9,62,70,71}$. Lower levels of circulating CC16 in children are associated with subsequent decreased lung function and increased risks of developing asthma and other respiratory diseases ${ }^{71-74}$.

\section{Other health effects}

Many in vitro and in vivo toxicological studies have provided evidence about genotoxic and cytotoxic effects induced by CBPs and the WHO International Agency for Research on Cancer acknowledges sufficient evidence for the carcinogenicity of chloroform and other widespread CBPs in animals ${ }^{75}$.

In humans, however, the epidemiologic evidence overall has generally been considered insufficient to declare CBPs to be carcinogenic, with bladder cancer presenting the most consistent evidence by providing the greatest likelihood of causality. It is worth noting that the majority of the studies evaluate the risk of cancer related to drinking water and not exposure in swimming-pools, so this lack of evidence should be considered with concern and not extrapolated. In fact, a recent study showed that for elite swimmers and their coaches, the levels of THMs in a Portuguese swimming-pool exceeded the limits for cancer risk ${ }^{76}$.

Regarding bladder cancer, several epidemiological studies have evaluated its risk in relation with CBPs, of which some are of sufficient quality to provide meaningful evidence towards causal inference, including meta-analysis ${ }^{77}$ and two pooled analyses ${ }^{78,79}$. While the majority were related to drinking water, there are also studies finding increased risk of bladder cancer related to showering, bathing, or swimming exposures to $\mathrm{THM}^{80-82}$.

Associations with other types of cancer have been suggested, namely melanoma risk associated with a history of swimming ${ }^{83}$ and colorectal cancer risk with CBPs exposure in drinking water ${ }^{84}$.

Regarding reproductive effects, there is no clear evidence linking CBPs exposure to poor pregnancy outcomes, except for a slight association with fetal growth-related outcomes and sporadic associations with some categories of congenital anomalies ${ }^{85}$.

Potential impact of CBPs on male fertility has been much less studied and is of great concern given the remarkable permeability of the scrotal skin. Most studies have addressed mainly the risks related to drinking water, while one study addressed the exposure through swimming-pool water and found that adolescents having attended indoor chlorinated-pools for $>250 \mathrm{~h}$ before the age of 10 years or $>125 \mathrm{~h}$ before the age of 7 years were three times more likely to have an abnormally low serum inhibin B and / or total testosterone than their peers who never visited these pools and those who attended outdoor chlorinated-pools or a copper-silver $\operatorname{pool}^{86}$.

\section{RISK FACTORS}

There is a complex interaction between the building environment, infectious agents, allergens, occupational exposures, school environment and recreational exposures, which contribute to shape the exposome ${ }^{3}$.

The amount and impact of CBPs exposure may be influenced by the dose of disinfectant, the resultant concentration of CBPs in the water and the air, the number of attending swimmers, temperature of water and air, ventilation rates in the building, duration of swimming, and the water turbulence ${ }^{2,87}$. The three routes of exposure (inhalation, ingestion and dermal absorption) vary for different age groups and are affected 
by several factors (Figure 2 ). Some conditions related to competitive swimmers are highlighted intable 3

Inhalation - Swimming-pool attendants inhale from the atmosphere just above the water's surface, and the volume of air inhaled is a function of the effort intensity and time. In indoor swimming-pools, individuals also breathe air in the wider area of the building housing the pool. A correlation between physical activity and THM concentrations ${ }^{88}$ has been identified.

Ingestion - Inadvertent water intake in the swimming-pool varies according to age and sex, with adult women ingesting the least and male children ingesting the most, especially babies.

Dermal/mucosal absorption - Chlorination of bathing water showed to change the dermal barrier function, especially of atopic skin ${ }^{89}$, the same being expected for chlorination of the swimming-pool water. Infant swimming practice combined with atopy has been shown to increase the prevalence of eczema ${ }^{90}$.

Age seems to be the most relevant personal risk factor for respiratory and reproductive health effects of CBPs exposure in swimming pools. The first years of life may be seen as a "window of sensitivity" given the progressive increase in maturation of respiratory tract and reproductive system.

Age also directly impacts the other risk factors, including the surface areas of both the head and the body, the breathing rate and body weight ${ }^{2}$. The contribution from each exposure route changes dramatically for each age group, and the time spent swimming must also be taken into consideration. Adjusted for body weight, the uptake of CBPs by all routes is clearly higher in infants or children and decreases with age. A schematic representation is presented infigure $\mathbf{3}$.

As previously mentioned, the use of indoor chlorinated-pools especially by young children interacts with atopic status to promote the development of childhood asthma ${ }^{52}$, and a synergistic action of exposure to pets and environmental tobacco smoke in chlorinated-pools attendants predisposes to the development of asthma $^{51}$.

\section{RECOGNIZING CBPs EXPOSURE-ASSOCIATED HEALTH EFFECTS}

Depending on the exposed epithelium, the level of exposure, the past medical history and/or certain individual characteristics, different signs and symptoms associated with CBPs exposure will be observed. These symptoms will be exacerbated in those patients with an underlying chronic inflammatory disease (asthma, eczema, allergy, dermatosis, etc.).

The diversity of tissues exposed to CBPs in swimming-pools attendants offers a wide variety of clinical conditions (summarized inTable 4 ), which require a differential diagnosis with other disorders that present similar symptoms and signs, although their history is different. More detailed information on this topic is provided as online supplementary material .

\section{MANAGEMENT}

Although evidence is lacking, there is consensus on the recommendation to assure that water treatment processes prevent CBPs formation in order to minimize the chance of an increased risk of cancer from its long-term exposure. Current standards for the assessment of THM exposure are mostly defined for the THM content in swimming-pool water, although THM are quite volatile and likely to be present in appreciable concentrations also in the air of indoor swimming-pool facilities. Though it has been progressively acknowledged that airborne THM levels have a central role in inducing CBP-related adverse health effects, there are presently no standards or guidelines for controlling THM levels in indoor air of swimming-pool amenities. There is currently no international standard for the treatment of swimming-pools, with different regulations often provided by state or local governing bodies.

Inhalation of airborne THM and other CBPs seems to be the predominant route of exposure for competitive swimmers, who have an increased breathing rate throughout their regular and prolonged sports and training actions and for coaches and other pool workers and staff, who experience an intense occupational exposure 
to the THM-rich environment that surrounds the pool. In fact, data on the real long-term exposure to CBPs and the risks that this exposure may represent for the health of competitive swimmers and coaches over the course of their careers is currently lacking. Nevertheless, a few easy and effective steps that all can take to maintain water and air quality are presented as a checklist in table $\mathbf{5}$.

\section{RECOMMENDATIONS AND UNMET NEEDS}

The expansion of indoor aquatic activities resulted in a major focus of public authorities and local legislators on the prevention of water-borne infectious diseases, through the implementation and inspection of water disinfection practices. Comparatively, much less attention has been dedicated from health authorities to the indoor air quality (IAQ) of aquatic facilities, and there are still unmet needs to guarantee a generally safe and healthy indoor sport environment for both recreational and professional swimmers, and to those involved in their instruction, training, safety vigilance and pool maintenance.

There is still very limited information regarding additional hazardous pollutants, such as volatile organic compounds (VOCs) other than CBPs and ultrafine particulate matter (UFPs), and their possible long-term and cumulative health effects on swimming-pool attendants ${ }^{103}$. No guidelines are defined for UFP or THM, except for occupational chloroform exposure.

Due to the presence of both indoor THM and non-THM VOC, effective ventilation and acclimatization systems are a particular need for indoor swimming facilities to prevent the accumulation and promote the effective elimination of these harmful chlorine-derived volatile compounds.

Among the available options for water disinfection, other than chlorine-derived solutions should be considered in the planning and development of new public indoor swimming-pools. For existing facilities, avoiding any factors that promote the development, introduction and retention of air pollutants, i.e. controlling pollutant sources and ventilation levels, constitute the major action plans proposed for IAQ improvements of swimming-pools ${ }^{103}$.

Proper maintenance schedules and ventilation conditions are needed to guarantee a stable indoor environment - temperature and relative humidity - in the areas of water activities. Water-related factors - air/water temperature ratio and $\mathrm{pH}$, the number of swimmers within the pool - also explain variations of the VOC levels found in the water-surface air, the air zone that is regularly inhaled by swimmers. Thus, maintaining water $\mathrm{pH}$ between 6.9 and 8.0 and air temperature $2{ }^{\circ} \mathrm{C}$ above the pool water are recommended to avoid level fluctuations and the undesired volatilization of CBP, particularly during periods of high attendance ${ }^{103}$. Recommendations concerning prophylactic procedures during occupational exposure are lacking but given the fluctuations of indoor pollutants concentrations found throughout a working day ${ }^{103}$, it is advisable that pool maintenance staff minimize occupational exposure by carrying in the early morning activities that require a prolonged stay in the swimming-pool surrounding area.

Checking declared indoor sources of VOC emissions, and the heating, ventilation and air conditioning (HVAC) systems (particulate matter filtration capacity and efficient removal of indoor pollutants), should also be considered $^{104}$, as well as the HVAC system design, in order to guarantee that fresh air supply and exhaust airflows do not mix by proximity.

Findings suggest that early and chronic exposure to swimming-pool CBP may have a promoting effect not only on airway inflammation and hyperreactivity, but also on the process of allergic sensitization itself. Other health outcomes, namely male fertility and bladder cancer, are of particular concern, as the majority of published studies evaluate these risks in relation to drinking water and not swimming-pools exposure. Early age exposure (baby and pre-school swimming) may turn to be a relevant personal risk factor for respiratory and reproductive health effects of BP exposure in swimming pools, given the progressive increase in maturation of respiratory tract and reproductive system.

There is still need of more environmental and epidemiological research data, to ascertain the health risk associated with the exposure of different swimming pool users, namely babies, infants and children, lifeguards 
and swimming pool maintenance staff, coaches and elite swimmers. Additional prospective and intervention studies are also needed to confirm the relationship between exposure to pollutants in swimming-pool environments and the risk of certain health effects.

\section{Contribution by each author}

MC, AB, LD; FD, MK, AM, RRA, MR, SS and MW each prepared and wrote one section of the manuscript. $\mathrm{MC}$ and SQ were responsible for collecting and integrating all sections and prepare the final versions. All authors reviewed and approved the last version of the manuscript.

\section{REFERENCES}

1. Geiger KR, Henschke N. Swimming for children and adolescents with asthma. Br J Sports Med 2015;49:8356

2. Dyck R, Sadiq R, Rodriguez MJ, Simard S, Tardif R. Trihalomethane exposures in indoor swimming pools: a level III fugacity model. Water Res 2011;45:5084-98

3. Agache I, Miller R, Gern JE, Hellings PW, Jutel M, Muraro A, Phipatanakul W, Quirce S, Peden D. Emerging concepts and challenges in implementing the exposome paradigm in allergic diseases and asthma. Allergy 2019;74:449-463

4. Zwiener C, Richardson SD, DeMarini DM, Grummt T, Glauner T, Frimmel FH. Drowning in disinfection byproducts? Assessing swimming pool water. Environ Sci Technol 2007;41:363-72

5. Weng S, Blatchley ER, 3rd. Disinfection by-product dynamics in a chlorinated, indoor swimming pool under conditions of heavy use: national swimming competition. Water Res 2011;45:5241-8

6. Keuten MG, Peters MC, Daanen HA, de Kreuk MK, Rietveld LC, van Dijk JC. Quantification of continual anthropogenic pollutants released in swimming pools. Water Res 2014;53:259-70

7. Carter RAA, Joll CA. Occurrence and formation of disinfection by-products in the swimming pool environment: A critical review. J Environ Sci (China) 2017;58:19-50

8. Manasfi T, Coulomb B, Boudenne JL. Occurrence, origin, and toxicity of disinfection byproducts in chlorinated swimming pools: An overview. Int J Hyg Environ Health 2017;220:591-603

9. Bernard A, Carbonnelle S, Dumont X, Nickmilder M. Infant swimming practice, pulmonary epithelium integrity, and the risk of allergic and respiratory diseases later in childhood. Pediatrics 2007;119:1095-103

10. Levesque B, Vezina L, Gauvin D, Leroux P. Investigation of Air Quality Problems in an Indoor Swimming Pool: A Case Study. Ann Occup Hyg 2015;59:1085-9

11. Gérardin F, Cloteaux A, Midoux N. Modeling of variations in nitrogen trichloride concentration over time in swimming pool water. Process Saf. Environ. Protect. 2015;94:452-62

12. Florentin A, Hautemaniere A, Hartemann P. Health effects of disinfection by-products in chlorinated swimming pools. Int J Hyg Environ Health 2011;214:461-9

13. Fantuzzi G, Righi E, Predieri G, Giacobazzi P, Mastroianni K, Aggazzotti G. Prevalence of ocular, respiratory and cutaneous symptoms in indoor swimming pool workers and exposure to disinfection byproducts (DBPs). Int J Environ Res Public Health 2010;7:1379-91

14. Jacobs JH, Spaan S, van Rooy GB, Meliefste C, Zaat VA, Rooyackers JM, Heederik D. Exposure to trichloramine and respiratory symptoms in indoor swimming pool workers. Eur Respir J 2007;29:690-8

15. Massin N, Bohadana AB, Wild P, Hery M, Toamain JP, Hubert G. Respiratory symptoms and bronchial responsiveness in lifeguards exposed to nitrogen trichloride in indoor swimming pools. Occup Environ Med $1998 ; 55: 258-63$ 
16. Rundell KW, Anderson SD, Sue-Chu M, Bougault V, Boulet LP. Air quality and temperature effects on exercise-induced bronchoconstriction. Compr Physiol 2015;5:579-610

17. Vandenplas O, Wiszniewska M, Raulf M, de Blay F, Gerth van Wijk R, Moscato G, Nemery B, Pala G, Quirce S, Sastre J, Schlunssen V, Sigsgaard T, Siracusa A, Tarlo SM, van Kampen V, Zock JP, WalusiakSkorupa J. EAACI position paper: irritant-induced asthma. Allergy 2014;69:1141-53

18. Thickett KM, McCoach JS, Gerber JM, Sadhra S, Burge PS. Occupational asthma caused by chloramines in indoor swimming-pool air. Eur Respir J 2002;19:827-32

19. Musch MW, Walsh-Reitz MM, Chang EB. Roles of ZO-1, occludin, and actin in oxidant-induced barrier disruption. Am J Physiol Gastrointest Liver Physiol 2006;290:G222-31

20. Bernard A. Chlorination products: emerging links with allergic diseases. Curr Med Chem 2007;14:1771-82

21. Parrat J, Donze G, Iseli C, Perret D, Tomicic C, Schenk O. Assessment of occupational and public exposure to trichloramine in Swiss indoor swimming pools: a proposal for an occupational exposure limit. Ann Occup Hyg 2012;56:264-77

22. Gardinier S, Guehenneux S, Latreille J, Guinot C, Tschachler E. Variations of skin biophysical properties after recreational swimming. Skin Res Technol 2009;15:427-32

23. Dalmau G, Martinez-Escala ME, Gazquez V, Pujol-Montcusi JA, Canadell L, Espona Quer M, Pujol RM, Vilaplana J, Gaig P, Gimenez-Arnau A. Swimming pool contact dermatitis caused by 1-bromo-3-chloro5,5-dimethyl hydantoin. Contact Dermatitis 2012;66:335-9

24. Fernandez-Luna A, Burillo P, Felipe JL, del Corral J, Garcia-Unanue J, Gallardo L. Perceived health problems in swimmers according to the chemical treatment of water in swimming pools. Eur J Sport Sci 2016;16:256-65

25. Sasseville D, Geoffrion G, Lowry RN. Allergic contact dermatitis from chlorinated swimming pool water. Contact Dermatitis 1999;41:347-8

26. Neering H. Contact urticaria from chlorinated swimming pool water. Contact Dermatitis 1977;3:279

27. Najnin N, Forbes A, Sinclair M, Leder K. Risk factors for community-based reports of gastrointestinal, respiratory, and dermal symptoms: findings from a cohort study in Australia. J Epidemiol 2014;24:39-46

28. Kelsall HL, Sim MR. Skin irritation in users of brominated pools. Int J Environ Health Res 2001;11:29-40

29. Goma A, de Lluis R, Roca-Ferrer J, Lafuente J, Picado C. Respiratory, ocular and skin health in recreational and competitive swimmers: Beneficial effect of a new method to reduce chlorine oxidant derivatives. Environ Res 2017;152:315-21

30. Carbonnelle S, Francaux M, Doyle I, Dumont X, de Burbure C, Morel G, Michel O, Bernard A. Changes in serum pneumoproteins caused by short-term exposures to nitrogen trichloride in indoor chlorinated swimming pools. Biomarkers 2002;7:464-78

31. Voisin C, Sardella A, Bernard A. Risks of new-onset allergic sensitization and airway inflammation after early age swimming in chlorinated pools. Int J Hyg Environ Health 2014;217:38-45

32. Kanikowska A, Napiórkowska-Baran K, Graczyk M, Kucharski MA. Influence of chlorinated water on the development of allergic diseases - An overview. Ann Agric Environ Med 2018;25:651-5

33. Shim JS, Lee HS, Park DE, Won Lee J, Bae B, Chang Y, Kim J, Kim HY, Kang HR. Aggravation of asthmatic inflammation by chlorine exposure via innate lymphoid cells and CD11 $c^{\text {intermediate }}$ macrophages. Allergy 2020;75:381-391.

34. Seki T, Morimatsu S, Nagahori H, Morohashi M. Free Residual Chlorine in Bathing Water Reduces the Water-Holding Capacity of the Stratum Corneum in Atopic Skin. J Dermatol 2003;30:196-202 
35. Fantuzzi G, Righi E, Predieri G, Giacobazzi P, Petra B, Aggazzotti G. Airborne trichloramine ( $\mathrm{NCl}(3)$ ) levels and self-reported health symptoms in indoor swimming pool workers: dose-response relationships. J Expo Sci Environ Epidemiol 2013;23:88-93

36. Chu TS, Cheng SF, Wang GS, Tsai SW. Occupational exposures of airborne trichloramine at indoor swimming pools in Taipei. Sci Total Environ 2013;461-462:317-22

37. Bureau G, Levesque B, Dube M, Gauvin D, Lepine F, Laliberte D. Indoor swimming pool environments and self-reported irritative and respiratory symptoms among lifeguards. Int J Environ Health Res 2017;27:306-22

38. Mountjoy M, Fitch K, Boulet L-P, Bougault V, van Mechelen W, Verhagen E. Prevalence and characteristics of asthma in the aquatic disciplines. J Allergy Clin Immunol 2015;136:588-94

39. Helenius I, Rytilä P, Metso P, Haahtela T, Venge P, Tikkanen H. Respiratory symptoms, bronchial responsiveness, and cellular characteristics of induced sputum in elite swimmers. Allergy 1998;53:346-52

40. Helenius I, Rytilä P, Sarna S, Lumme A, Helenius M, Remes V, Haahtela T. Effect of continuing or finishing high-level sports on airway inflammation, bronchial hyperresponsiveness, and asthma: a 5-year prospective follow-up study of 42 highly trained swimmers. J Allergy Clin Immunol 2002;109:962-8

41. Bougault V, Odashiro P, Turmel J, Orain M, Laviolette M, Joubert P, Boulet LP. Changes in airway inflammation and remodelling in swimmers after quitting sport competition. Clin Exp Allergy 2018:48:174851

42. Kurowski M, Jurczyk J, Olszewska-Ziaber A, Jarzebska M, Krysztofiak H, Kowalski ML. A similar pro/anti-inflammatory cytokine balance is present in the airways of competitive athletes and non-exercising asthmatics. Adv Med Sci 2018;63:79-86

43. Moreira A, Palmares C, Lopes C, Delgado L. Airway vascular damage in elite swimmers. Respir Med. 2011;105:1761-5

44. Gabrilo G, Peric M, Stipic M. Pulmonary function in pubertal synchronized swimmers: 1-year follow-up results and its relation to competitive achievement. Med Probl Perform Art 2001;26:39-43

45. Gelardi M, Ventura MT, Fiorella R, Fiorella ML, Russo C, Candreva T, Carretta A, Passalacqua G. Allergic and non-allergic rhinitis in swimmers: clinical and cytological aspects. Br J Sports Med. 2012;46:548

46. Surda P, Walker A, Limpens J, Fokkens W, Putala M. Nasal changes associated with exercise in athletes: systematic review. J Laryngol Otol. 2018;132:191-197

47. Metelitsa A, Barankin B, Lin AN. Diagnosis of sports-related dermatoses. Int J Dermatol 2004;43:113-9

48. Basler RSW, Basler GC, Palmer AH, Garcia MA. Special skin symptoms seen in swimmers. J Am Acad Dermato 2000;43:299-305

49. Fernández-Luna Á, Burillo P, Felipe JL, del Corral J, García-Unanue J, Gallardo L. Perceived health problems in swimmers according to the chemical treatment of water in swimming pools. Eur J Sport Sci 2016;16:256-65

50. Kujundzić M, Braut T, Manestar D, Cattunar A, Malvić G, Vukelić J, Puselja Z, Linsak D. Water related otitis externa. Coll Antropol 2012;36:893-7

51. Bernard A, Carbonnelle S, Michel O, Higuet S, De Burbure C, Buchet JP, Hermans C, Dumont X, Doyle I. Lung hyperpermeability and asthma prevalence in schoolchildren: unexpected associations with the attendance at indoor chlorinated swimming pools. Occup Environ Med 2003;60:385-94

52. Bernard A, Carbonnelle S, de Burbure C, Michel O, Nickmilder M. Chlorinated pool attendance, atopy, and the risk of asthma during childhood. Environ Health Perspect 2006;114:1567-73 
53. Bernard A, Nickmilder M, Voisin C, Sardella A. Impact of chlorinated swimming pool attendance on the respiratory health of adolescents. Pediatrics 2009;124:1110-8

54. Andersson M, Backman H, Nordberg G, Hagenbjork A, Hedman L, Eriksson K, Forsberg B, Ronmark E. Early life swimming pool exposure and asthma onset in children - a case-control study. Environ Health $2018 ; 17: 34$

55. Andersson M, Hedman L, Nordberg G, Forsberg B, Eriksson K, Ronmark E. Swimming pool attendance is related to asthma among atopic school children: a population-based study. Environ Health 2015;14:37

56. Cotter A, Ryan CA. The pool chlorine hypothesis and asthma among boys. Ir Med J 2009;102:79-82

57. Ferrari M, Schenk K, Mantovani W, Papadopoulou C, Posenato C, Ferrari P, Poli A, Tardivo S. Attendance at chlorinated indoor pools and risk of asthma in adult recreational swimmers. J Sci Med Sport 2011;14:184-9

58. Cavaleiro Rufo J, Paciencia I, Silva D, Martins C, Madureira J, Oliveira Fernandes E, Padrao P, Moreira $\mathrm{P}$, Delgado L, Moreira A. Swimming pool exposure is associated with autonomic changes and increased airway reactivity to a beta-2 agonist in school aged children: A cross-sectional survey. PLoS One 2018;13:e0193848

59. Font-Ribera L, Villanueva CM, Gracia-Lavedan E, Borras-Santos A, Kogevinas M, Zock JP. Indoor swimming pool attendance and respiratory and dermal health in schoolchildren-HITEA Catalonia. Respir Med 2014;108:1056-9

60. Font-Ribera L, Villanueva CM, Ballester F, Santa Marina L, Tardon A, Espejo-Herrera N, Esplugues A, Rodriguez Dehli C, Basterrechea M, Sunyer J. Swimming pool attendance, respiratory symptoms and infections in the first year of life. Eur J Pediatr 2013;172:977-85

61. Font-Ribera L, Villanueva CM, Nieuwenhuijsen MJ, Zock JP, Kogevinas M, Henderson J. Swimming pool attendance, asthma, allergies, and lung function in the Avon Longitudinal Study of Parents and Children cohort. Am J Respir Crit Care Med 2011;183:582-8

62. Jacobs JH, Fuertes E, Krop EJ, Spithoven J, Tromp P, Heederik DJ. Swimming pool attendance and respiratory symptoms and allergies among Dutch children. Occup Environ Med 2012;69:823-30

63. Bernard A, Voisin C, Sardella A. Con: respiratory risks associated with chlorinated swimming pools: a complex pattern of exposure and effects. Am J Respir Crit Care Med 2011;183:570-2

64. Klootwijk T, Krul M. Some concerns remain about the proposed association between swimming and asthma. Am J Respir Crit Care Med 2011;184:1419; author reply -20

65. Kohlhammer Y, Doring A, Schafer T, Wichmann HE, Heinrich J. Swimming pool attendance and hay fever rates later in life. Allergy 2006;61:1305-9

66. Voisin C, Sardella A, Bernard A. Allergic sensitization and airway inflammation after early swimming. Am J Respir Crit Care Med 2013;187:1392-4

67. Voisin C, Sardella A, Bernard A. Risks of new-onset allergic sensitization and airway inflammation after early age swimming in chlorinated pools. Int J Hyg Environ Health 2014;217:38-45

68. Nystad W, Nja F, Magnus P, Nafstad P. Baby swimming increases the risk of recurrent respiratory tract infections and otitis media. Acta Paediatr 2003;92:905-9

69. Voisin C, Sardella A, Marcucci F, Bernard A. Infant swimming in chlorinated pools and the risks of bronchiolitis, asthma and allergy. Eur Respir J 2010;36:41-7

70. Lagerkvist BJ, Bernard A, Blomberg A, Bergstrom E, Forsberg B, Holmstrom K, Karp K, Lundstrom NG, Segerstedt B, Svensson M, Nordberg G. Pulmonary epithelial integrity in children: relationship to ambient ozone exposure and swimming pool attendance. Environ Health Perspect 2004;112:1768-71 
71. Bernard A, Nickmilder M, Dumont X. Chlorinated pool attendance, airway epithelium defects and the risks of allergic diseases in adolescents: Interrelationships revealed by circulating biomarkers. Environ Res 2015;140:119-26

72. Kurowski M, Jurczyk J, Jarzebska M, Moskwa S, Makowska JS, Krysztofiak H, Kowalski ML. Association of serum Clara cell protein CC16 with respiratory infections and immune response to respiratory pathogens in elite athletes. Respir Res 2014;15:45

73. Zhu L, An L, Ran D, Lizarraga R, Bondy C, Zhou X, Harper RW, Liao SY, Chen Y. The Club Cell Marker SCGB1A1 Downstream of FOXA2 is Reduced in Asthma. Am J Respir Cell Mol Biol 2019;60:695-704

74. Zhai J, Insel M, Addison KJ, Stern DA, Pederson W, Dy A, Rojas-Quintero J, Owen CA, Sherrill DL, Morgan W, Wright AL, Halonen M, Martinez FD, Kraft M, Guerra S, Ledford JG. Club Cell Secretory Protein Deficiency Leads to Altered Lung Function. Am J Respir Crit Care Med 2019;199:302-12

75. IARC. International Agency for Research on Cancer Monographs on the evaluation of carcinogenic risks to humans. Some chemicals that cause tumors of the kidney or urinary bladder in rodents and some other substances, Lyon 1999.

76. Gouveia P, Felgueiras F, Mourao Z, Fernandes EO, Moreira A, Gabriel MF. Predicting health risk from exposure to trihalomethanes in an Olympic-size indoor swimming pool among elite swimmers and coaches. J Toxicol Environ Health A 2019;82:577-90

77. Villanueva CM, Fernandez F, Malats N, Grimalt JO, Kogevinas M. Meta-analysis of studies on individual consumption of chlorinated drinking water and bladder cancer. J Epidemiol Community Health 2003;57:16673

78. Villanueva CM, Cantor KP, Cordier S, Jaakkola JJ, King WD, Lynch CF, Porru S, Kogevinas M. Disinfection byproducts and bladder cancer: a pooled analysis. Epidemiology 2004;15:357-67

79. Costet N, Villanueva CM, Jaakkola JJ, Kogevinas M, Cantor KP, King WD, Lynch CF, Nieuwenhuijsen MJ, Cordier S. Water disinfection by-products and bladder cancer: is there a European specificity? A pooled and meta-analysis of European case-control studies. Occup Environ Med 2011;68:379-85

80. Villanueva CM, Cantor KP, Grimalt JO, Malats N, Silverman D, Tardon A, Garcia-Closas R, Serra C, Carrato A, Castano-Vinyals G, Marcos R, Rothman N, Real FX, Dosemeci M, Kogevinas M. Bladder cancer and exposure to water disinfection by-products through ingestion, bathing, showering, and swimming in pools. Am J Epidemiol 2007;165:148-56

81. Panyakapo M, Soontornchai S, Paopuree P. Cancer risk assessment from exposure to trihalomethanes in tap water and swimming pool water. J Environ Sci (China) 2008;20:372-8

82. Beane Freeman LE, Cantor KP, Baris D, Nuckols JR, Johnson A, Colt JS, Schwenn M, Ward MH, Lubin JH, Waddell R, Hosain GM, Paulu C, McCoy R, Moore LE, Huang AT, Rothman N, Karagas MR, Silverman DT. Bladder Cancer and Water Disinfection By-product Exposures through Multiple Routes: A Population-Based Case-Control Study (New England, USA). Environ Health Perspect 2017;125:067010

83. Nelemans PJ, Rampen FH, Groenendal H, Kiemeney LA, Ruiter DJ, Verbeek AL. Swimming and the risk of cutaneous melanoma. Melanoma Res 1994;4:281-6

84. Rahman MB, Driscoll T, Cowie C, Armstrong BK. Disinfection by-products in drinking water and colorectal cancer: a meta-analysis. Int J Epidemiol 2010;39:733-45

85. Villanueva CM, Cordier S, Font-Ribera L, Salas LA, Levallois P. Overview of Disinfection By-products and Associated Health Effects. Curr Environ Health Rep 2015;2:107-15

86. Nickmilder M, Bernard A. Associations between testicular hormones at adolescence and attendance at chlorinated swimming pools during childhood. Int J Androl 2011;34:e446-58 
87. Chu H, Nieuwenhuijsen MJ. Distribution and determinants of trihalomethane concentrations in indoor swimming pools. Occup Environ Med 2002;59:243-7

88. van Veldhoven K, Keski-Rahkonen P, Barupal DK, Villanueva CM, Font-Ribera L, Scalbert A, Bodinier B, Grimalt JO, Zwiener C, Vlaanderen J, Portengen L, Vermeulen R, Vineis P, Chadeau-Hyam M, Kogevinas M. Effects of exposure to water disinfection by-products in a swimming pool: A metabolome-wide association study. Environ Int 2018;111:60-70

89. Seki T, Morimatsu S, Nagahori H, Morohashi M. Free residual chlorine in bathing water reduces the water-holding capacity of the stratum corneum in atopic skin. J Dermatol 2003;30:196-202

90. Chaumont A, Voisin C, Sardella A, Bernard A. Interactions between domestic water hardness, infant swimming and atopy in the development of childhood eczema. Environ Res 2012;116:52-7

91. Carbonnelle S, Bernard A, Doyle IR, Grutters J, Francaux M. Fractional exhaled NO and serum pneumoproteins after swimming in a chlorinated pool. Med Sci Sports Exerc 2008;40:1472-6

92. Font-Ribera L, Kogevinas M, Zock JP, Gomez FP, Barreiro E, Nieuwenhuijsen MJ, Fernandez P, Lourencetti C, Perez-Olabarria M, Bustamante M, Marcos R, Grimalt JO, Villanueva CM. Shortterm changes in respiratory biomarkers after swimming in a chlorinated pool. Environ Health Perspect 2010;118:1538-44

93. Fernandez-Luna A, Gallardo L, Plaza-Carmona M, Garcia-Unanue J, Sanchez-Sanchez J, Felipe JL, Burillo P, Ara I. Respiratory function and changes in lung epithelium biomarkers after a short-training intervention in chlorinated vs. ozone indoor pools. PLoS One 2013;8:e68447

94. Font-Ribera L, Marco E, Grimalt JO, Pastor S, Marcos R, Abramsson-Zetterberg L, Pedersen M, Grummt T, Junek R, Barreiro E, Heederik D, Spithoven J, Critelli R, Naccarati A, Schmalz C, Zwiener C, Liu J, Zhang X, Mitch W, Gracia-Lavedan E, Arjona L, de Bont J, Tares L, Vineis P, Kogevinas M, Villanueva CM. Exposure to disinfection by-products in swimming pools and biomarkers of genotoxicity and respiratory damage - The PISCINA2 Study. Environ Int 2019;131:104988

95. Nickmilder M, Bernard A. Ecological association between childhood asthma and availability of indoor chlorinated swimming pools in Europe. Occup Environ Med 2007;64:37-46

96. Bernard A, Nickmilder M, Voisin C. Outdoor swimming pools and the risks of asthma and allergies during adolescence. Eur Respir J 2008;32:979-88

97. Nystad W, Haberg SE, London SJ, Nafstad P, Magnus P. Baby swimming and respiratory health. Acta Paediatr 2008;97:657-62

98. Schoefer Y, Zutavern A, Brockow I, Schafer T, Kramer U, Schaaf B, Herbarth O, von Berg A, Wichmann HE, Heinrich J. Health risks of early swimming pool attendance. Int J Hyg Environ Health 2008;211:367-73

99. Schuez-Havupalo L, Karppinen S, Toivonen L, Kaljonen A, Jartti T, Waris M, Peltola V. Association between infant swimming and rhinovirus-induced wheezing. Acta Paediatr 2014;103:1153-8

100. Bernard A, Sardella A, Voisin C, Dumont X. Nasal epithelium injury by chlorination products and other stressors predicts persistent sensitization to aeroallergens in young schoolchildren. Environ Res 2017;158:14552

101. Marco E, Lourencetti C, Grimalt JO, Gari M, Fernandez P, Font-Ribera L, Villanueva CM, Kogevinas M. Influence of physical activity in the intake of trihalomethanes in indoor swimming pools. Environ Res 2015;140:292-9

102. Bozym M, Wzorek M, Klosok-Bazan I. Health risk as a consequence of exposure to trihalomethanes in swimming pool water. Rocz Panstw Zakl Hig 2017;68:331-7 
103. Felgueiras F, Mourão Z, Morais C, Santos H, Gabriel MF, de Oliveira Fernandes E. Comprehensive assessment of the indoor air quality in a chlorinated Olympic-size swimming pool. Environ Int 2020;136:105401.

104. Gabriel MF, Felgueiras F, Mourão Z, Fernandes EO. Assessment of the air quality in 20 public indoor swimming pools located in the Northern Region of Portugal. Environ Int 2019;133(Pt B):105274

Table 1 : Studies describing short-term changes in respiratory biomarkers.

\begin{tabular}{|c|c|c|c|}
\hline Authors & Conditions & Biomarkers & Main findings \\
\hline $\begin{array}{l}\text { Carbonnelle et al. } 2002 \\
(30)\end{array}$ & $\begin{array}{l}\text { Chlorinated-pool }\left(\mathrm{NCl}_{3}\right. \\
\text { mean concentration: } 490 \\
\left.\mu \mathrm{g} / \mathrm{m}^{3}\right) \text { for recreational } \\
\text { swimmers. } \\
\text { Chlorinated-pool }\left(\mathrm{NCl}_{3}\right. \\
\text { mean concentration: } 355 \\
\left.\mu \mathrm{g} / \mathrm{m}^{3}\right) \mathrm{Vs} \text { copper/silver } \\
\text { pool for trained } \\
\text { swimmers }\end{array}$ & $\begin{array}{l}\text { Serum SP-A, SP-B and } \\
\text { CC16 }\end{array}$ & $\begin{array}{l}\text { CC16 was not increased } \\
\text { in recreational swimmers } \\
\text { In trained swimmers } \\
\text { CC16 peaked } \\
\text { immediately after } \\
\text { strenuous exercise, both } \\
\text { in the copper/silver and } \\
\text { in the chlorinated pools } \\
\text { SP-A and SP-B were } \\
\text { unaffected by strenuous } \\
\text { exercise in the } \\
\text { copper/silver pool SP-A } \\
\text { and SP-B were } \\
\text { significantly increased in } \\
\text { a time-dependent manner } \\
\text { in recreational and } \\
\text { trained swimmers } \\
\text { attending the } \\
\text { chlorinated-pool }\end{array}$ \\
\hline $\begin{array}{l}\text { Carbonnelle et al. } 2008 \\
(91)\end{array}$ & $\begin{array}{l}\text { Chlorinated-pool }\left(\mathrm{NCl}_{3}\right. \\
\text { concentration: } 160-280 \\
\left.\mu \mathrm{g} / \mathrm{m}^{3}\right) \text { Vs } \\
\text { copper } / \text { silver-pool }\left(\mathrm{NCl}_{3}\right. \\
\left.<20 \mu \mathrm{g} / \mathrm{m}^{3}\right)\end{array}$ & $\begin{array}{l}\text { FeNO; serum SP-A, } \\
\text { SP-B, CC16, KL-6 }\end{array}$ & $\begin{array}{l}\text { FeNO increased in the } \\
\text { copper/silver pool, } \\
\text { whereas it did not change } \\
\text { in the chlorinated-pool, } \\
\text { suggesting that } \\
\text { chlorination might inhibit } \\
\text { NO-induced vasodilation } \\
\text { in exercise Serum } \\
\text { pneumoproteins were } \\
\text { unchanged excepted } \\
\text { SP-A which decreased } \\
\text { after exercise in the } \\
\text { chlorinated pool (P < } \\
0.05)\end{array}$ \\
\hline $\begin{array}{l}\text { Font-Ribera et al. } 2010 \\
(92)\end{array}$ & Chlorinated indoor pool & $\begin{array}{l}\text { FeNO; serum SP-D and } \\
\text { CC16; 8-isoprostane, } \\
\text { several cytokines* and } \\
\text { VEGF in EBC }\end{array}$ & $\begin{array}{l}\text { CC16 slightly increased } \\
\text { after a swimming session } \\
\text { No significant changes in } \\
\text { lung function, SP-D, } \\
\text { 8-isoprostane, cytokines, } \\
\text { or VEGF. }\end{array}$ \\
\hline
\end{tabular}




\begin{tabular}{|c|c|c|c|}
\hline Authors & Conditions & Biomarkers & Main findings \\
\hline $\begin{array}{l}\text { Fernández-Luna et al. } \\
2013(93)\end{array}$ & $\begin{array}{l}\text { Chlorinated-pool Vs } \\
\text { ozone-treated pool }\end{array}$ & Serum SP-D and CC16 & $\begin{array}{l}\text { No change was observed } \\
\text { in lung function and } \\
\text { SP-D in swimmers } \\
\text { attending both pools } \\
\text { CC16 was significantly } \\
\text { increased in subjects } \\
\text { attending the } \\
\text { chlorinated-pool but not } \\
\text { in those using the } \\
\text { ozone-treated pool }\end{array}$ \\
\hline $\begin{array}{l}\text { Font-Ribera et al. } 2019 \\
(94)\end{array}$ & $\begin{array}{l}\text { Chlorinated-pool }\left(\mathrm{NCl}_{3}\right. \\
\text { mean concentration: } 473 \\
\left.\mu \mathrm{g} / \mathrm{m}^{3}\right)\end{array}$ & $\begin{array}{l}\text { Serum CC16; exhaled } \\
\text { breath THMs; urinary } \\
\text { TCAA; genotoxicity } \\
\text { biomarkers }\end{array}$ & $\begin{array}{l}\text { Creatinine-adjusted } \\
\text { urinary TCAA increased } \\
\text { by } 3.1 \mu \mathrm{mol} / \mathrm{mol} \text { Urine } \\
\text { mutagenicity, MN-PBL, } \\
\text { MN-Ret and serum CC16 } \\
\text { levels remained } \\
\text { unchanged after } \\
\text { swimming No correlation } \\
\text { between CBP exposure } \\
\text { and MN-PBL, urine } \\
\text { mutagenicity and CC16 } \\
\text { Moderate associations } \\
\text { observed for MN-Ret and } \\
\text { CBP exposure }\end{array}$ \\
\hline
\end{tabular}

* RANTES, Ip10, TNF, IL-12p70, IL-10, IL-8, IFN- $\gamma$, IL-4.

\# Urine mutagenicity, micronuclei in peripheral blood lymphocytes (MN-PBL) and micronuclei in reticulocytes (MN-Ret).

CC: Clara cell protein; CBP: chlorination by-products; EBC: exhaled breath condensate; FeNO: fractional exhaled nitric oxide; KL-6: Krebs von den Lungen-6 protein; TCAA: Trichloroacetic acid; THMs: Trihalomethanes; SP: Surfactant-associated protein; VEGF: vascular endothelial growth factor.

Table 2: Risks of respiratory diseases, aeroallergen sensitization and airway epithelial defects associated with recreational swimming in indoor and/or outdoor chlorinated-pools. 


\begin{tabular}{|c|c|c|c|c|c|c|}
\hline Authors & Country & Country & $\begin{array}{l}\text { Type of } \\
\text { study }\end{array}$ & N (age, yrs) & $\mathrm{NCl}_{3} \mathrm{mg} / \mathrm{m}^{3}$ & $\begin{array}{l}\text { Main } \\
\text { findings }\end{array}$ \\
\hline $\begin{array}{l}\text { Bernard et al. } \\
2003(51)\end{array}$ & Belgium & Belgium & Cross-sectional & $\begin{array}{l}226(8-12) \\
1,881(7-14)\end{array}$ & - & $\begin{array}{l}\text { Dose-effect } \\
\text { relation } \\
\text { between } \\
\text { CCPA and } \\
\text { serum SP-A } \\
\text { and SP-B } \\
(n=226) \text {. } \\
\text { Correlations } \\
\text { between the } \\
\text { prevalence of } \\
\text { asthma and } \\
\text { the CCPA } \\
(n=1881) .\end{array}$ \\
\hline $\begin{array}{l}\text { Nystad et al. } \\
2003(68)\end{array}$ & Norway & Norway & $\begin{array}{l}\text { Cross- } \\
\text { sectional }\end{array}$ & $\begin{array}{l}2,862 \\
\text { children }\end{array}$ & - & $\begin{array}{l}\text { Increased } \\
\text { risk of } \\
\text { recurrent } \\
\text { respiratory } \\
\text { tract } \\
\text { infections in } \\
\text { baby } \\
\text { swimmers } \\
\text { from atopic } \\
\text { parents } \\
\text { (aOR, 2.08, } \\
95 \% \text { CI: } \\
1.08-4.031) .\end{array}$ \\
\hline $\begin{array}{l}\text { Lagerkvist } \\
\text { et al. } 2004 \\
(70)\end{array}$ & Sweden & Sweden & $\begin{array}{l}\text { Cross- } \\
\text { sectional }\end{array}$ & $57(10-11)$ & - & $\begin{array}{l}\text { Significant } \\
\text { decrease of } \\
\text { serum CC16 } \\
\text { in children } \\
(\mathrm{n}=20) \\
\text { regularly } \\
\text { visiting } \\
\text { indoor } \\
\text { chlorinated- } \\
\text { pools }\end{array}$ \\
\hline $\begin{array}{l}\text { Kohlhammer } \\
\text { et al. } 2006 \\
(65)\end{array}$ & Germany & Cross-sectional & Cross-sectional & $2,606(35-74)$ & - & $\begin{array}{l}\text { Dose-related } \\
\text { associations } \\
\text { between the } \\
\text { risk of hay } \\
\text { fever and the } \\
\text { current and } \\
\text { school-age } \\
\text { pool } \\
\text { attendance. }\end{array}$ \\
\hline
\end{tabular}




\begin{tabular}{|c|c|c|c|c|c|c|}
\hline Authors & Country & Country & $\begin{array}{l}\text { Type of } \\
\text { study }\end{array}$ & $\mathbf{N}$ (age, yrs) & $\mathrm{NCl}_{3} \mathrm{mg} / \mathrm{m}^{3}$ & $\begin{array}{l}\text { Main } \\
\text { findings }\end{array}$ \\
\hline $\begin{array}{l}\text { Bernard et } \\
\text { al. } 2006(52)\end{array}$ & Belgium & Belgium & $\begin{array}{l}\text { Cross- } \\
\text { sectional }\end{array}$ & $341(10-13)$ & $0.25-0.54$ & $\begin{array}{l}\text { Increased } \\
\text { risk of } \\
\text { asthma } \\
\text { (doctor- } \\
\text { diagnosed or } \\
\text { EIB) with } \\
\text { CCPA in } \\
\text { children } \\
\text { with serum } \\
\text { IgE }>100 \\
\text { kIU/L (aOR } \\
\text { for each } \\
\text { 100-hr } \\
\text { increase in } \\
\text { CCPA = } \\
1.79 ; 95 \% \\
\text { CI, } \\
1.07-2.72) .\end{array}$ \\
\hline $\begin{array}{l}\text { Nickmilder } \\
\text { and Bernard, } \\
2007(95)\end{array}$ & Belgium & Belgium & Ecological & $(13-14)(6-7)$ & - & $\begin{array}{l}\text { In both age } \\
\text { groups, the } \\
\text { prevalence of } \\
\text { ever asthma } \\
\text { across Europe } \\
\text { correlated } \\
\text { with the } \\
\text { availability of } \\
\text { indoor } \\
\text { chlorinated- } \\
\text { pools. }\end{array}$ \\
\hline $\begin{array}{l}\text { Bernard et } \\
\text { al. } 2007 \text { (9) }\end{array}$ & Belgium & Belgium & $\begin{array}{l}\text { Cross- } \\
\text { sectional }\end{array}$ & $341(10-13)$ & - & $\begin{array}{l}\text { Decrease of } \\
\text { serum CC16 } \\
\text { and higher } \\
\text { risks of } \\
\text { asthma and } \\
\text { bronchitis in } \\
43 \text { children } \\
\text { who swam } \\
\text { in indoor } \\
\text { chlorinated- } \\
\text { pools during } \\
\text { infancy }\end{array}$ \\
\hline
\end{tabular}




\begin{tabular}{|c|c|c|c|c|c|c|}
\hline Authors & Country & Country & $\begin{array}{l}\text { Type of } \\
\text { study }\end{array}$ & N (age, yrs) & $\mathrm{NCl}_{3} \mathrm{mg} / \mathrm{m}^{3}$ & $\begin{array}{l}\text { Main } \\
\text { findings }\end{array}$ \\
\hline $\begin{array}{l}\text { Bernard et } \\
\text { al. } 2008(96)\end{array}$ & Belgium & Belgium & $\begin{array}{l}\text { Cross- } \\
\text { sectional }\end{array}$ & $847(13-18)$ & - & $\begin{array}{l}\text { Use of } \\
\text { outdoor } \\
\text { pools was } \\
\text { associated } \\
\text { with higher } \\
\text { risks of } \\
\text { elevated } \\
\text { FeNO, cat } \\
\text { or HDM } \\
\text { sensitization } \\
\text { and asthma } \\
\text { in subjects } \\
\text { with serum } \\
\text { IgE > } 25 \\
\mathrm{kIU} / \mathrm{L}\end{array}$ \\
\hline $\begin{array}{l}\text { Nystad et al. } \\
2008(97)\end{array}$ & Norway & Norway & Prospective & $\begin{array}{l}30,870 \\
(0.5-1.5)\end{array}$ & - & $\begin{array}{l}\text { Increased risk } \\
\text { of wheeze } \\
(\mathrm{aOR}, 1.24, \\
95 \% \text { CI } 1.11 \text {, } \\
1.39) \text { in baby } \\
\text { swimmers } \\
\text { from atopic } \\
\text { mothers. }\end{array}$ \\
\hline $\begin{array}{l}\text { Schoefer et } \\
\text { al. } 2008 \text { (98) }\end{array}$ & Germany & Germany & Prospective & $2,196(6)$ & - & $\begin{array}{l}\text { Baby } \\
\text { swimmers } \\
\text { had higher } \\
\text { risk of } \\
\text { asthma } \\
\text { (aOR } 2.15 \\
95 \% \text { CI } \\
1.16-3.99) \\
\text { due } \\
\text { potentially } \\
\text { to reverse } \\
\text { causation } \\
\text { and } \\
\text { respiratory } \\
\text { infections in } \\
\text { the 1st yr }\end{array}$ \\
\hline $\begin{array}{l}\text { Cotter and } \\
\text { Ryan } 2009 \\
(56)\end{array}$ & Ireland & Ireland & $\begin{array}{l}\text { Cross- } \\
\text { sectional }\end{array}$ & $97(6-12)$ & - & $\begin{array}{l}\text { Associations } \\
\text { between } \\
\text { CCPA and } \\
\text { the risk of } \\
\text { diagnosed } \\
\text { asthma and } \\
\text { wheezing in } \\
\text { the last } 12 \\
\text { months }\end{array}$ \\
\hline
\end{tabular}




\begin{tabular}{|c|c|c|c|c|c|c|}
\hline Authors & Country & Country & $\begin{array}{l}\text { Type of } \\
\text { study }\end{array}$ & $\mathrm{N}$ (age, yrs) & $\mathrm{NCl}_{3} \mathrm{mg} / \mathrm{m}^{3}$ & $\begin{array}{l}\text { Main } \\
\text { findings }\end{array}$ \\
\hline $\begin{array}{l}\text { Bernard et } \\
\text { al. } 2009(53)\end{array}$ & Belgium & Belgium & $\begin{array}{l}\text { Cross- } \\
\text { sectional }\end{array}$ & $847(13-18)$ & $0.30-0.50$ & $\begin{array}{l}\text { Among } \\
\text { atopic } \\
\text { adolescents, } \\
\text { aOR for } \\
\text { asthma, hay } \\
\text { fever or } \\
\text { allergic } \\
\text { rhinitis } \\
\text { increased } \\
\text { with CCPA } \\
\text { but not with } \\
\text { the Cu/Ag } \\
\text { pool } \\
\text { attendance. }\end{array}$ \\
\hline $\begin{array}{l}\text { Voisin et al. } \\
2010(69)\end{array}$ & Belgium & Belgium & $\begin{array}{l}\text { Cross- } \\
\text { sectional }\end{array}$ & $430(5-7)$ & - & $\begin{array}{l}\text { Infant } \\
\text { swimming in } \\
\text { indoor or } \\
\text { outdoor } \\
\text { chlorinated- } \\
\text { pools is } \\
\text { associated } \\
\text { with } \\
\text { increased } \\
\text { risks of } \\
\text { bronchiolitis } \\
\text { and later of } \\
\text { allergic } \\
\text { sensitization }\end{array}$ \\
\hline $\begin{array}{l}\text { Font-Ribera et } \\
\text { al. } 2011(61)\end{array}$ & UK & UK & Prospective & $\begin{array}{l}5,738 \text { ( } 7 \text { and } \\
10)\end{array}$ & - & $\begin{array}{l}\text { Swimming was } \\
\text { associated } \\
\text { with increased } \\
\text { lung function } \\
\text { and lower risk } \\
\text { of asthma } \\
\text { symptoms. }\end{array}$ \\
\hline $\begin{array}{l}\text { Ferrari et al. } \\
2011(57)\end{array}$ & Italy & Italy & Prospective & $\begin{array}{l}1,136 \\
(18-55)\end{array}$ & - & $\begin{array}{l}\text { Higher risk } \\
\text { of new-onset } \\
\text { asthma } \\
\text { associated } \\
\text { with CCPA. }\end{array}$ \\
\hline
\end{tabular}




\begin{tabular}{|c|c|c|c|c|c|c|}
\hline Authors & Country & Country & $\begin{array}{l}\text { Type of } \\
\text { study }\end{array}$ & N (age, yrs) & $\mathrm{NCl}_{3} \mathrm{mg} / \mathrm{m}^{3}$ & $\begin{array}{l}\text { Main } \\
\text { findings }\end{array}$ \\
\hline $\begin{array}{l}\text { Jacobs et al. } \\
2012(62)\end{array}$ & Netherlands & Netherlands & Cross-sectional & $2,359(6-13)$ & 0.21 & $\begin{array}{l}\text { Association of } \\
\text { HDM } \\
\text { sensitization } \\
\text { with frequent } \\
\text { baby } \\
\text { swimming and } \\
\text { lower serum } \\
\text { CC16 } \\
\text { (n=419). No } \\
\text { association } \\
\text { with asthma. }\end{array}$ \\
\hline $\begin{array}{l}\text { Font-Ribera et } \\
\text { al. } 2013(60)\end{array}$ & Spain & Spain & Prospective & $2,205(0-1.17)$ & - & $\begin{array}{l}\text { No association } \\
\text { between } \\
\text { indoor or } \\
\text { outdoor } \\
\text { swimming } \\
\text { pool } \\
\text { attendance } \\
\text { during the 1st } \\
\text { year of life and } \\
\text { LRTI, } \\
\text { wheezing, } \\
\text { atopic eczema } \\
\text { or otitis }\end{array}$ \\
\hline $\begin{array}{l}\text { Voisin et al. } \\
2013,2014 \\
(66,67)\end{array}$ & Belgium & Belgium & Prospective & $\begin{array}{l}196(5.7 \text { and } \\
7.7)\end{array}$ & - & $\begin{array}{l}\text { Swimming at } \\
\text { indoor or } \\
\text { outdoor } \\
\text { chlorinated- } \\
\text { pools before } \\
\text { the age of } 3 \\
\text { yrs was } \\
\text { associated } \\
\text { with higher } \\
\text { risks of HDM } \\
\text { sensitization } \\
\text { and increased } \\
\text { FeNO }\end{array}$ \\
\hline $\begin{array}{l}\text { Schuez- } \\
\text { Havupalo et } \\
\text { al. } 2014 \text { (99) }\end{array}$ & Finland & Finland & Prospective & $1,827(0-1.42)$ & - & $\begin{array}{l}\text { Association } \\
\text { between infant } \\
\text { swimming and } \\
\text { rhinovirus- } \\
\text { associated } \\
\text { wheezing } \\
\text { among } \\
\text { children with } \\
\text { atopic eczema } \\
\text { (n=635, p = } \\
0.006) .\end{array}$ \\
\hline
\end{tabular}




\begin{tabular}{llllll}
\hline Authors & Country & Country & $\begin{array}{l}\text { Type of } \\
\text { study }\end{array}$ & $\mathbf{N}(\mathbf{a g e}, \mathbf{y r s})$ & $\mathbf{N C l}_{\mathbf{3}} \mathbf{m g} / \mathbf{m}^{\mathbf{3}}$ \\
\hline $\begin{array}{l}\text { Font-Ribera } \\
\text { et al. } 2014\end{array}$ & Spain & Spain & $\begin{array}{l}\text { Cross- } \\
\text { (59) }\end{array}$ & & sectional
\end{tabular}

Main

findings

No

associations

between

regular

indoor pool

attendance

before $2 \mathrm{yrs}$

and asthma,

wheezing,

Bernard et

Belgium

Belgium

Cross-

$835(13-18)$

al. 2015 (81)

sectional

eczema.

Associations

of serum

CC16/SP-D

with CCPA,

allergic

sensitization

(especially

to HDM)

and allergic

diseases

among

sensitized

adolescents

Andersson et Sweden

Sweden

Cross-section

$1,866(11-12)$

al. 2015 (55)

Bernard et al. Belgium

2017 (100)

Belgium

Prospective

$121(5.8,7.8)$

Asthma associated with indoor pool

attendance

([?]1 week)

only among

sensitized

subjects $(\mathrm{n}=$

1,652, aOR1.9, $95 \%$ CI

1.09-3.32).

Low CC16 in

NALF

associated

with CCPA

predicts

persistent

sensitization

to

aeroallergens, especially to HDM 


\begin{tabular}{|c|c|c|c|c|c|c|}
\hline Authors & Country & Country & $\begin{array}{l}\text { Type of } \\
\text { study }\end{array}$ & $\mathbf{N}$ (age, yrs) & $\mathrm{NCl}_{3} \mathrm{mg} / \mathrm{m}^{3}$ & $\begin{array}{l}\text { Main } \\
\text { findings }\end{array}$ \\
\hline $\begin{array}{l}\text { Cavaleiro- } \\
\text { Rufo et al. } \\
2018 \text { (58) }\end{array}$ & Portugal & Portugal & $\begin{array}{l}\text { Cross- } \\
\text { sectional }\end{array}$ & $858(7-12)$ & - & $\begin{array}{l}\text { Indoor pool } \\
\text { attendance } \\
\text { associated } \\
\text { with } \\
\text { autonomic } \\
\text { changes and } \\
\text { baseline } \\
\text { bronchocon- } \\
\text { striction and } \\
\text { before } 3 \text { yrs } \\
\text { with } \\
\text { functional } \\
\text { asthma }\end{array}$ \\
\hline $\begin{array}{l}\text { Andersson } \\
\text { et al. } 2018 \\
(54)\end{array}$ & Sweden & Sweden & Prospective & $970(16-17)$ & 0.15 & $\begin{array}{l}\text { Early indoor } \\
\text { pool } \\
\text { attendance } \\
(<3 \text { yrs }) \\
\text { associated } \\
\text { with asthma } \\
\text { onset. Risks } \\
\text { are } \\
\text { particularly } \\
\text { high for } \\
\text { atopics. } \\
\text { Dose- } \\
\text { response } \\
\text { relationships } \\
\text { with } \mathrm{NCl}_{3} \text {. }\end{array}$ \\
\hline
\end{tabular}

CCPA, cumulative chlorinated-pool attendance; CC16, club cell protein ; FeNO: fractional exhaled nitric oxide; SP-A, surfactant associated protein A ; SP-D, surfactant-associated protein D; HDM, house dust mite; LRTI, lower respiratory tract infection; EIB, exercise-induced bronchoconstriction ; $\mathrm{NCl}_{3}$, nitrogen trichloride or trichloramine in pool air; $\mathrm{Cu} / \mathrm{Ag}$ pool, swimming pool disinfected by copper /silver electrofiltration. Age and $\mathrm{NCl}_{3}$ values are reported as mean or range.

Table 3 : Conditions inherent to the competitive swimmers and the respective consequences on their exposure to disinfection by-products.

Condition Consequence

High physical effort

The internal dose of THMs increases significantly with intensity of physical activity (101 Stronger impact of the inhalation route compared to ingestion or dermal absorption

Oral inhalation of water droplets Increases the amount of exposure and may also alter the lung microbiome Greater swimming skills Lower rate of ingestion in a comparable time than for less skilled users

Table 4 : Differential diagnosis of the Chlorine exposure-related clinical conditions in pool attendants. 


\begin{tabular}{|c|c|c|c|}
\hline organ or system & $\begin{array}{l}\text { Pathology (SIGNS \& } \\
\text { symptoms) }\end{array}$ & Diagnosis & Differential diagnosis \\
\hline Hair & $\begin{array}{l}\text { Hair coloration/ } \\
\text { discoloration, fragile } \\
\text { and/or dry }\end{array}$ & $\begin{array}{l}\text { Clinical History Medical } \\
\text { examination }\end{array}$ & Other abrasive agents \\
\hline Eyes & $\begin{array}{l}\text { Corneal epithelial } \\
\text { erosions or dysfunction } \\
\text { Conjunctivitis }\end{array}$ & $\begin{array}{l}\text { Clinical History Medical } \\
\text { examination } \\
\text { Clinical History Medical } \\
\text { examination }\end{array}$ & $\begin{array}{l}\text { Corneal abrasion } \\
\text { Recurrent corneal erosion } \\
\text { Allergic conjunctivitis } \\
\text { Irritative conjunctivitis }\end{array}$ \\
\hline Ear & $\begin{array}{l}\text { External Otitis } \\
\text { "Swimmer's Ear" }\end{array}$ & $\begin{array}{l}\text { Clinical History Medical } \\
\text { examination }\end{array}$ & $\begin{array}{l}\text { Skin injuries, foreign } \\
\text { bodies, chronic } \\
\text { inflammation }\end{array}$ \\
\hline Nails & $\begin{array}{l}\text { Surface damage of the } \\
\text { nail plates }\end{array}$ & $\begin{array}{l}\text { Clinical History Medical } \\
\text { examination }\end{array}$ & $\begin{array}{l}\text { Fungal infection Nail } \\
\text { polish effects }\end{array}$ \\
\hline Teeth & Enamel erosion & $\begin{array}{l}\text { Clinical History Medical } \\
\text { Examination }\end{array}$ & $\begin{array}{l}\text { Attrition and abrasion of } \\
\text { the enamel }\end{array}$ \\
\hline Skin & $\begin{array}{l}\text { Dry, itching, fragile skin } \\
\text { Eczema }\end{array}$ & $\begin{array}{l}\text { Clinical History Medical } \\
\text { Examination }\end{array}$ & $\begin{array}{l}\text { "Primary" eczema } \\
\text { Dermatoses and systemic } \\
\text { illnesses with dry skin }\end{array}$ \\
\hline \multirow[t]{3}{*}{ Respiratory system } & Nose itching & $\begin{array}{l}\text { Clinical History Medical } \\
\text { Examination Skin prick } \\
\text { tests }\end{array}$ & Allergic rhinitis \\
\hline & Anosmia & $\begin{array}{l}\text { Clinical History Medical } \\
\text { Examination Olfactive } \\
\text { tests Imaging }\end{array}$ & $\begin{array}{l}\text { Allergic rhinitis } \\
\text { Obstructive/traumatic } \\
\text { nasal diseases } \\
\text { Sensorineural diseases of } \\
\text { the olfactive tract }\end{array}$ \\
\hline & $\begin{array}{l}\text { Dyspnea, respiratory } \\
\text { fatigue, cough, wheezing, } \\
\text { chest tightness, muscular } \\
\text { fatigue }\end{array}$ & $\begin{array}{l}\text { Clinical History Medical } \\
\text { Examination } \\
\text { Complementary test: } \\
\text { Spirometry } \\
\text { pre/post-exposure, } \\
\text { Monitored exercise test, } \\
\text { pre/post- exercise DLCO, } \\
\text { Skin prick tests }\end{array}$ & $\begin{array}{l}\text { Dyspneic pathologies: } \\
\text { Cardiovascular } \\
\text { Respiratory Hematology } \\
\text { Oncology Rheumatology } \\
\text { immunology } \\
\text { Environmental stress ... }\end{array}$ \\
\hline
\end{tabular}

Table 5. Healthy swimming water and air quality checklist, based on the recommendations of the Centers for Disease Control and Prevention and the guidelines from the World Health Organization.

\section{Swimmers checklist}

Table 5. Healthy swimming water and air quality checklist, based on the recommendations of the Centers for Disease Control and Prevention and the guidelines from the World Health Organization.

Stay out of the water if you have: - diarrhea (for patients with cryptosporidiosis, don't swim for an additional 2 weeks after diarrhea has resolved) - a gastrointestinal (stomach) upset or skin or respiratory infection - an open wound (for example, from surgery or a piercing) that is not covered with a waterproof bandage Keep ears as dry as possible and dry ears thoroughly after swimming 


\section{Swimming pool checklist}

Shower before you get into the water, rinsing off in the shower for just 1 min removes most of the dirt or anything else on your body Remove make-up Don't pee or poop in the water Don't swallow the water Check the pool's latest inspection results Check the free chlorine level and $\mathrm{pH}$ before getting into the water: proper free chlorine level (1-3 $\mathrm{mg} / \mathrm{L}$ or parts per million) and $\mathrm{pH}(7.2-7.8)$ maximize germ-killing power.

\section{Figures legends:}

Figure 1 : Chlorination by-products presented at the water and the air of chlorinated swimming-pools adapted from Bernard A (20).

Figure 2 : The routes of exposure to disinfection by-products in swimming-pools and the factors affecting each route - adapted from Dyck et al (2).

Figure 3: Schematic representation of the relation between water ingestion and surface area/body mass and respiratory rates throughout different ages (based on data from WHO Training package for the Health sector - Children's health and the environment).

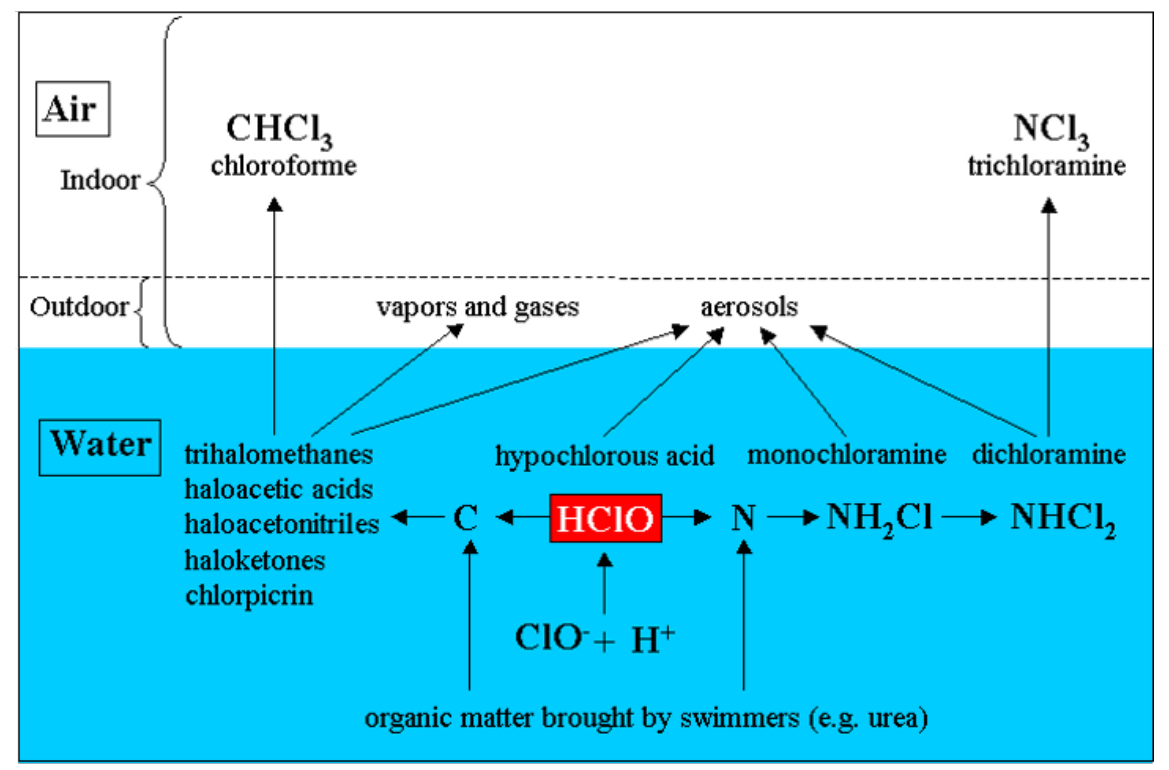



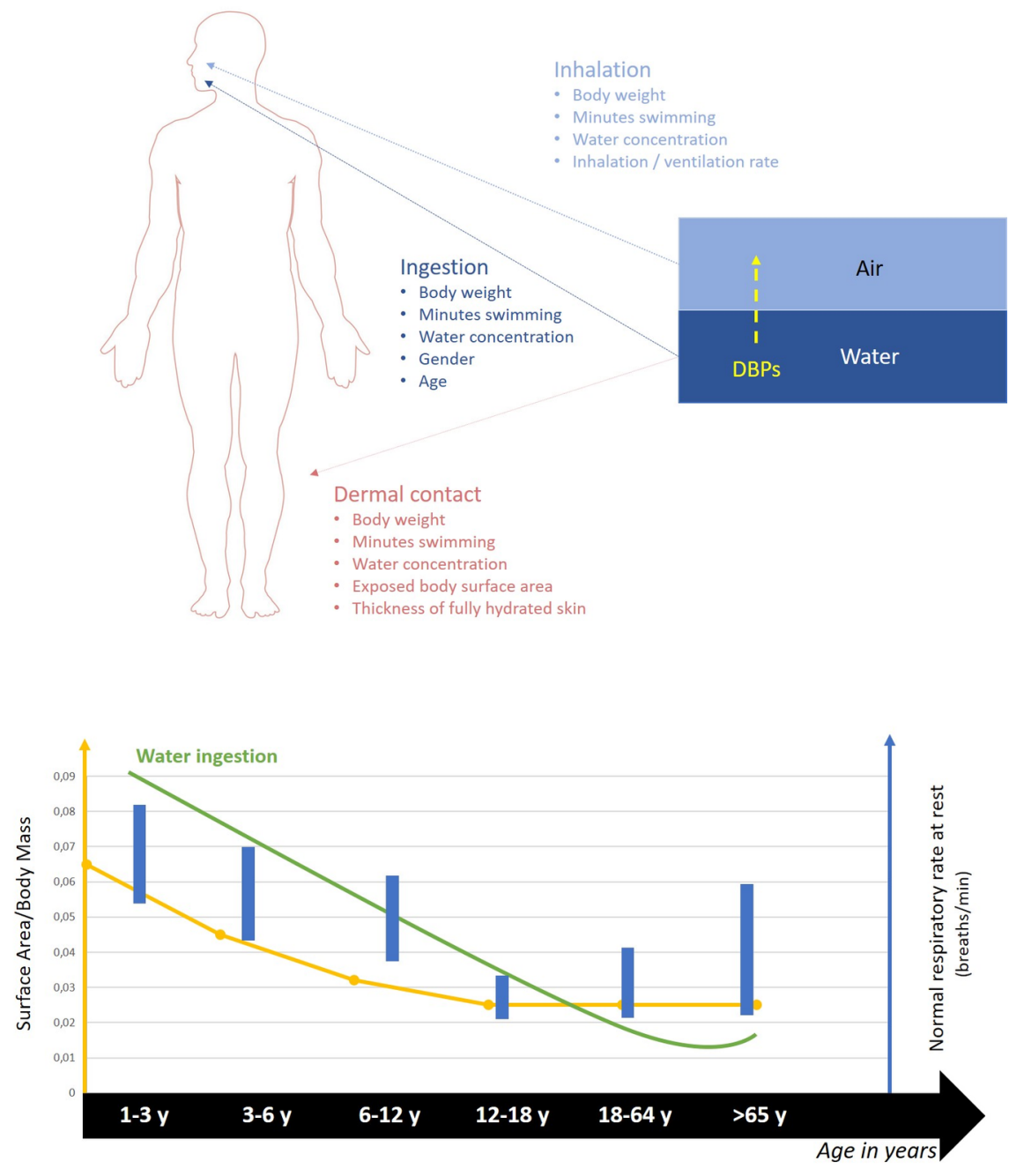